\title{
A Study of the Antioxidative Substance(s) in Squid Mantle Muscle
}

\author{
Ichiro Komatsu*,**, Toshitaka YasudA ${ }^{*}$, Kenji FukunaGA*, \\ Tetsuya SuzukI ${ }^{* * * *}$, Satoru Suzuki ${ }^{*}$ and Kozo TAKama* \\ * Laboratory of Food Hygiene, Department of Food Science and \\ Technology, Faculty of Fisheries, Hokkaido University, \\ Hakodate, Hokkaido 041
}

\begin{abstract}
The lipid peroxidation suppressing ability of whole lipid extracted from commercially purchased squid mantle muscle of three common squids, i. e., Japanese common squid (Todarodes pacificus), flying squid (Ommastrephes bartrami) and short-finned squid (Illex argentinus), was evaluated by the progress of peroxide value (PV) and carbonyl value (CV) of purified sardine oil with or without addition of whole lipid fraction at $10 \%$ level. Every whole lipid extracted from the three species of squid markedly suppressed the peroxidation of purified sardine oil. The whole lipid of $I$. argentinus showed the strongest suppressive activity of the three. Neither differences in compositions of lipid and fatty acids nor content and composition of tocopherols in the mantle muscle could sufficiently account for their antioxidative ability. The addition of purified phospholipid fraction, fractionated from the whole lipid of $I$. argentinus, to purified sardine oil at the concentration of $5 \%(\mathrm{w} / \mathrm{w})$ markedly suppressed the peroxidation of sardine oil.
\end{abstract}

With increasing demand for natural antioxidants to replace artificial ones such as butylated hydroxytoluene (BHT), butylated hydroxyanisole (BHA), which in recent times the food industry has been reluctant to use because of their questionable safety, efforts to replace them by novel natural antioxidants are being made ${ }^{1)-3}$. As a result, antioxidants in marine organisms have become a subject of great interest $^{4 / 5)}$.

In Japan, a large quantity of squid is consumed raw and/or as a dry processed food. In spite of the fact that these processed squid have a large content of polyunsaturated fatty acids that are susceptible to lipid peroxidation, squid products usually do not pose any problem of rancidity during the processing such as air drying ${ }^{6) 7)}$. This study examined whether or not lipids in squid mantle muscle have lipid peroxidation suppressing ability.

\section{Materials and Methods}

\section{Materials}

Samples used in the present study were Japanese common squid (Todarodes pacificus) (average mantle length, $230 \mathrm{~mm}$; average body weight, $250 \mathrm{~g}$ ), flying squid (Ommastrephes bartrami) (average mantle length, $290 \mathrm{~mm}$; average body weight, $370 \mathrm{~g}$ ) and short-finned squid (Illex argentinus) (average mantle length, $250 \mathrm{~mm}$; average body weight, $370 \mathrm{~g}$ ). All samples were provided in the frozen state. Purified sardine oil, used as the specimen for determination of $\mathrm{PV}$ and $\mathrm{CV}$ as indices of lipid peroxidation, was kindly supplied by Nippon Kagaku Shiryo Co., Ltd. (Hakodate, Japan).

Evaluation of antioxidative activity of squid lipids

The lipid peroxidation suppressing ability of squid lipids was evaluated by comparing PV

** Present address : Otsuka Chemical Co. Ltd., Food \& Beverage Research, Tokushima, 771-01

*** To whom all correspondence should be mailed. 
and CV as follows: one gram each of the whole lipid extracted from each of the three different squid mantle muscles according to the method of Folch et al ${ }^{8)}$ were separately mixed with $9 \mathrm{~g}$ of a purified sardine oil. The mixtures were placed in petri dishes (70 $\mathrm{mm}$ in diameter) and incubated at $37^{\circ} \mathrm{C}$ in the dark. $P V^{5)}$ and $\mathrm{CV}^{9)}$ were periodically measured and compared between the three different squid lipids. As a control, purified sardine oil was incubated under the same condition. For determining lipid peroxidation suppression ability for the phospholipid fraction, $150 \mathrm{mg}$ of phospholipid fraction, fractionated by gel permeation chromatography according to the method of TIPTON et $a l .{ }^{10)}$, from the whole lipid fraction of $I$. argentinus was added to purified sardine oil $(3 \mathrm{~g})$. PV and CV of the mixture was measured periodically during incubation as described above, but in this case the incubation temperature was set at $50^{\circ} \mathrm{C}$.

\section{Analysis of lipid composition of squid mantle muscle}

In order to make it clear whether or not lipid oxidation suppression ability differs with changes in whole lipid composition and/or phospholipid composition, whole lipid and phospholipid compositions were analyzed by thin-layer chromatography on a Silica Gel 70 plate $(0.25 \mathrm{~mm}$ thick; Wako Pure Chemical Ind. Ltd., Osaka). As the first step, each plate was developed with a solvent system ( $n$-hexane : diethyl ether : acetic acid $=80: 20$ : 1 , by vol.). For the second step $^{11)}$, this was followed by developing with another solvent system (chloroform : methanol : acetic acid: water $=25: 15: 4: 2$, by vol.). Phospholipid was further analyzed by a two single dimensional thin-layer chromatography ; i. e., for the first step development acetone: diethyl ether $=1: 1$, by vol, and the second step development chloroform : methanol : acetic acid : water $=25: 1: 4: 2$, by vol. were used ${ }^{11}$. The proportion of individual lipid component was determined densitometrically with a Cosmo Model F-808 densitometer (Cosmo Co. Ltd., Tokyo) ${ }^{12)}$. The total phospholipid content was determined by Fiske-Subbarow's method ${ }^{13}$.
To examine the possibility that the lipid peroxidation suppression is due to tocopherols, the whole squid lipid, tocopherol content and composition of the whole lipid was analyzed. The whole lipid extract $(3 \sim 4 \mathrm{~g})$ from the skinned mantle muscle was mixed with $9 \mathrm{~m} l$ of a mixture of $1 \%$ pyrogaloll, $60 \%$ methanol and $1.5 \mathrm{ml}$ of $50 \% \mathrm{KOH}$. Saponification was carried out at $90^{\circ} \mathrm{C}$ for $45 \mathrm{~min}$. A small volume of water was added to the saponified alkaline whole lipid solution, and tocopherols were extracted by $n$-hexane. The extract was concentrated to $4.5 \mathrm{~m} l$ under vacuo. The obtained tocopherol fraction was subjected to a quantitative analysis of isomers by high-performance liquid chromatography using a Cosmosil $5 \mathrm{SL}$
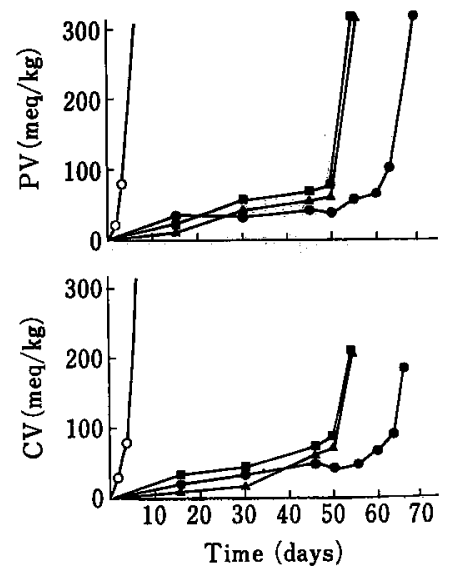

Fig. 1 Time course of suppression of peroxidation of purified sardine oil by whole lipid fraction extracted from mantle muscle of three different squid species

To $9 \mathrm{~g}$ of the purified sardine oil, $1 \mathrm{~g}$ of whole lipid fraction extracted from mantle muscle of three different squid species was separately added and the mixture was incubated at $37^{\circ} \mathrm{C}$ for the indicated time.

Experimental details are described in Materials and Methods.

$\bigcirc$, purified sardine alone; $\boldsymbol{\square}, T$. pacificus ; $\mathbf{\Lambda}, O$. bartrami;,$I$. argentinus The change of PV $(\mathrm{meq} / \mathrm{kg})$ with time (day) is represented in the top panel, and that of $\mathrm{CV}(\mathrm{meq} / \mathrm{kg})$ is in the bottom panel. 
column $(150 \times 4.6 \mathrm{~mm}$ i. d. ; Nacalai Tesque Inc., Kyoto) on a Shimadzu LC- $5 \mathrm{~A}$ high performance liquid chromatograph equipped with a Shimadzu Fluorescence Monitor RF-530 (Excitation $298 \mathrm{~nm}$; Emission $325 \mathrm{~nm}$ ) as a detector. The mobile phase used was $n$-hexane : ethanol: dioxane $(95.8: 0.2: 4.0$, by vol.). The flow rate was kept at $1.0 \mathrm{ml} / \mathrm{min}$.

\section{Results}

Antioxidative activity of whole lipid extracted from squid

The effect on changes of $\mathrm{PV}$ and $\mathrm{CV}$ in sardine oil as a result of adding total lipid extract obtained from three different species of squid mantle muscle was examined. In comparison to purified sardine oil alone, the peroxidation of purified sardine oil was markedly suppressed by the addition of total lipid extract obtained from each of the three different species of squid mantle muscle down to the level of $10 \%$ (Fig. 1). The length of time taken to reach rancid state, $i . e ., 100 \mathrm{meq} / \mathrm{kg}$ as $\mathrm{PV}$ and $\mathrm{CV}$, was $51 \sim 75$ days when whole lipid of squid was added to sardine oil. However, it took only 4 days for sardine oil alone to reach the same level. The total lipids extracted from mantle muscle of the three squid species obviously showed antioxidative activity. In particular, extract from 1 . argentinus displayed the most potent effect of the squid species examined. Similar results were obtained by an incubation system using methyl linoleate or linoleic acid $^{14)}$. The antioxidative stability of squid lipid themselves, however, was not examined.

Comparison between lipid composition of three different squid mantle muscles

To examine where the antioxidative effect originated, lipid compositions of the three squid mantle muscle were compared (Table 1). Table 1 shows that phospholipid was the major constituent of the extracted lipids. Phospholipid contents in the total lipid from $T$. pacificus, $O$. bartrami and $I$. argentinus were $71.7 \%, 61.8 \%$ and $73.4 \%$, respectively. As to the phospholipid composition, phosphatidylcholine (PC) and phosphatidylethanolamine (PE) in $T$. pacificus, and $I$. argentinus were the major components, occupying $38.9 \sim 54.7 \%$ of the total phospholipids. However, the contents of $\mathrm{PC}$ and $\mathrm{PE}$ in $O$. bartrami were lower than those of the other two squid species.

Cholesterol was the second major component in the whole lipid fraction. However, triacylglycerol was present only in a small amount.

Table 1 Compositions of whole lipid and phospholipid obtained from the mantle muscle of three different squid species

(A) Whole lipid composition

\begin{tabular}{lccccc}
\hline \hline & $\mathrm{PL}^{*}$ & $\mathrm{~S}$ & FFA & TG & Others \\
\hline T. pacificus & 71.7 & 19.9 & 6.5 & 0.8 & 1.1 \\
O. bartrami & 61.8 & 15.8 & 21.6 & 0.1 & 0.7 \\
I. argentinus & 73.1 & 15.4 & 6.8 & 3.2 & 1.5 \\
\hline
\end{tabular}

(B) Phospholipid composition comprising whole lipid

\begin{tabular}{lclllc}
\hline & LPC/SPM & PC & PS & PE & Unidentified \\
\hline T. pacificus & 7.5 & 31.5 & 8.9 & 19.7 & 4.1 \\
O. bartrami & 12.4 & 22.1 & 7.8 & 16.8 & 2.7 \\
I. argentinus & 9.6 & 31.5 & 5.4 & 23.2 & 3.4 \\
\hline
\end{tabular}

Values are expressed as relative weight percent.*, Individual component of total phospholipid are given in Table 1-(B).

Abbr. : PL, phospholipid; S, sterol; FFA, free fatty acid; TG, triacylglycerol; others, sterol esters and unidentified compound(s); LPC/SPM, lysophoshatidylcholine and/or sphingomyelin; PC, phosphatidylcholine; PS, phosphatidylserine; PE, phosphatidylethanolamine 
Free fatty acid content in $O$. bartrami was considerably high. This suggests that hydrolysis of phospholipid took place during storage of the squid. Lipids listed as unidentified in Table 1 may include sterol esters and melanoidine-like browning substance(s).

The peroxidation suppression effect of whole squid lipid against purified sardine oil was thought to be attributed to tocopherols in the whole lipid fraction. Total tocopherol contents in the whole lipid fraction from mantle muscle of the three different squid are shown in Fig. 2. Total tocopherol content in $O$. bartrami was the highest of the three squid species. However, the total squid lipid which showed the most potent peroxidation suppres.

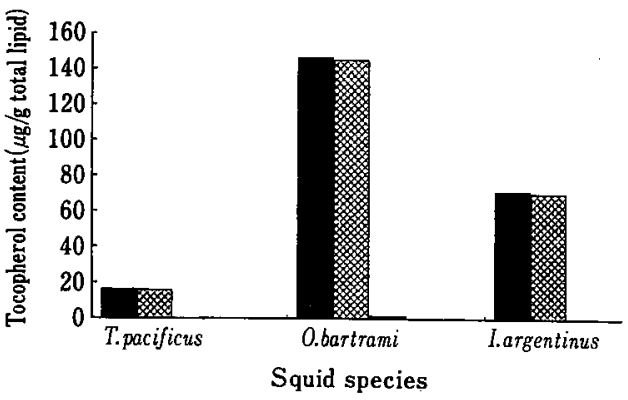

Fig. 2 Tocopherol contents in the whole lipid fraction extracted from the mantle muscle of three different squid species

Values are expressed as $\mu \mathrm{g} / \mathrm{g}$ of whole lipid.

, total tocopherol content ; , $\alpha$-tocopherol content; $\boldsymbol{\square}, \gamma$-tocopherol

Since the contents of $\gamma$-tocopherol and $\delta$ tocopherol were too low in comparison to those of total tocopherol and $\alpha$-tocopherol, columns are not drawn in the graph except for $\gamma$-tocopherol in $O$. bartrami. $\beta$-Tocopherol was not detected from any samples examined. The contents of $\gamma$-tocopherol and $\delta$-tocopherol in $T$. pacificus were 0.30 and $0.08 \mu \mathrm{g} / \mathrm{g}$ of whole lipid, respectively, and those in $O$. bartrami were 1.78 and $0.21 \mu \mathrm{g} / \mathrm{g}$ of whole lipid. The content of $\delta$-tocopherol in $I$. argentinus was $0.89 \mu \mathrm{g} / \mathrm{g}$ of whole lipid, but $\gamma$-tocopherol was not detected. sion effect was not that from $O$. bartrami but from 1 . argentinus. On the other hand, of the three squid species, the content of $\delta$-tocopherol, known to have the most potent antioxidative activity, was the highest in the total lipid of $I$. argentinus. The peroxidation suppression effect of the total lipid from squid mantle muscle could be explained by the contribution of tocopherols.

On the other hand, several papers have reported that phospholipid prevents lipid peroxidation ${ }^{15)}$. Although the antioxidative effect of phospholipids has been denied by OLCotT and van DEEN ${ }^{16)}$, several studies suggest the antioxidative potential of phospholipid ${ }^{172-19}$. Therefore, we tried to examine whether phospholipid fractionated from the total lipid of short-finned squid (I. argentinus) could show any suppressive effect on lipid peroxidation of purified sardine.

Phospholipid fraction from the total lipid of I. argentinus was added to purified sardine oil at a level of $5 \%$. The loading test result is shown in Fig. 3. Purified phospholipid fraction from $I$. argentinus showed evidence of antioxidative activity. The addition of purified phospholipid fraction to the sardine oil definitely delayed the time required to reach rancid state (PV : $100 \mathrm{meq} / \mathrm{kg}$; CV : $100 \mathrm{meq} /$ $\mathrm{kg}$ ). It required approximately 5.3 times as long as that of sardine oil alone.

\section{Discussion}

Concerning the mechanism of antioxidative activity of squid mantle lipid, several possibilities can be considered; (1) antioxidative effect of tocopherols, (2) synergistic effect of phospholipid and tocopherols, (3) the presence of novel unknown antioxidative substance(s) in the lipid fraction, and (4) antioxidative effect of phospholipid.

Accounting the result to the antioxidant effect arisen from tocopherols is not enough. The contents and compositions of tocopherols in the squid mantle muscles did not account for the difference in the antioxidaut activity. Little $\delta$-tocopherol content having antioxidative effect was found in squid mantle muscle; 


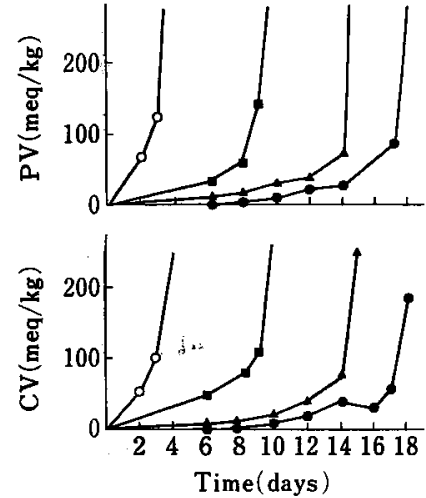

Fig. 3 Comparison of antioxidative activity of phospholipid fraction and non-phospholipid fraction prepared from squid whole lipid fraction against purified sardine oil

To $3 \mathrm{~g}$ of purified sardine oil $150 \mathrm{mg}$ of each fraction prepared from $I$. argentinus was separately added, and the mixture was incubated at $50^{\circ} \mathrm{C}$ in the dark.

$O$, purified sardine oil alone;

mixture with non-phospholipid fraction;

A, mixture with phospholipid fraction;

- mixture with whole lipid from $I$. argentinus

The changes of PV (meq $/ \mathrm{kg})$ with time elapsed (day) are given in the top panel, and those of $\mathrm{CV}(\mathrm{meq} / \mathrm{kg})$ are given in the bottom panel.

i.e., the content of tocopherols other than $\alpha$-tocopherol did not seem high enough to act as antioxidant. In addition, there was no accounting for the difference in antioxidative activity of the whole lipid fraction from the squid mantle muscles. Furthermore, the difference in antioxidative effect could not be explained by the $\delta$-tocopherol content, either.

The antioxidative activity of whole lipid from the mantle muscles of the three species of squid examined showed different extent of antioxidant activity. The lipid composition of $T$. pacificus was similar to that of $I$. argentinus, but antioxidative effect of total lipids from those two species differed from each other. It is, therefore, difficult to explain the difference in the antioxidant effect by their lipid compositions. Furthermore, any novel substances which may contribute to an anti- oxidative effect were not detected by thin-layer chromatography. Though there were some differences in the composition of the whole lipid fraction among these three squid species, each whole lipid fraction was considerably rich in highly polyunsaturated fatty acids such as eicosapentaenoic acid and docosahexaenoic acid. Major fatty acids in the fraction were : $\mathrm{C}_{16: 0}(33.6 \sim 37.7 \%), \mathrm{C}_{20: 5}(8.2 \sim 13.2 \%)$, and $\mathrm{C}_{22: 6}(28.4 \sim 28.7 \%)$. The content of monounsaturated fatty acids was relatively low $(10.2 \sim 12.8 \%)$.

Phospholipid, the major constituent of the squid mantle lipid, suppressed peroxidation of purified sardine oil. The possibility can be excluded that traces of tocopherol, present in either the squid phospholipid fraction or purified sardine oil, exhibited antioxidative effect in cooperation with phospholipid as synergist. This is because the contents of total tocopherol in squid phospholipid $(0.84$ $\mu \mathrm{g} / \mathrm{g}$ ) from $I$. argentinus and in purified sardine oil $(2.03 \mu \mathrm{g} / \mathrm{g})$ were considered to be too low to act as primary antioxidant. This point will be discussed in detail elsewhere ${ }^{14)}$.

Similar facts dealing with the antioxidative activity of phospholipids and related compounds have been reported ${ }^{17) \sim 19)}$.

YAMAGUCHI et al. ${ }^{20)}$ reported that lipids extracted from plaice, stripped pigfish and several other fishes exhibited oxidative stability. The degree of stability of these lipids were correlated with their total phospholipid contents and composition. Further, they ${ }^{15)}$ attempted to make clear the mechanism of antioxidative action of phospholipids by using isolated phospholipid from total lipid of the ordinary muscle of plaice with methyl linoleate as the critical standard material. They suggested that phospholipid per se could not play a role as a primary antioxidant but would act as a synergist against $\alpha$-tocopherol.

Studies on the participation of phospholipid base in the suppression of lipid peroxidation were carried out by TAKAGI et $a l .{ }^{21)}$, TERAO ${ }^{22)}$, KANEDA and his colleagues ${ }^{23)}{ }^{24)}$. However, there have been no detailed studies at the molecular level on the antioxidative activity of 
squid lipids.

Sardine oil of ten contains small amounts of tocopherols as a trace contaminant. These are only slightly removed by a conventional purification procedure. A possibility was inferred that the antioxidative effect of squid phospholipid might be due to the synergistic effect of tocopherols contained in purified sardine oil ${ }^{1 *}$. Similar antioxidative phenomenon has been observed by experiments using methyl linoleate as an evaluation standard material in place of sardine oil ${ }^{14)}$. This occurred where the content of tocopherols in the purified phospholipid was ca. $40 \mathrm{ng} / \mathrm{g}$ in the incubation mixture.

To explain the antioxidation mechanism of squid phospholipid, it is still necessary to make a detailed model experiment by using purified individual constituent of phospholipid fraction and a highly refined substrate. Detailed studies with purified squid phospholipid are now being undertaken.

An interesting and necessary point is the oxidative stability of the components comprising the whole lipid fraction of the squid. However, in the present study we did not evaluate the oxidative stability of lipid and/or lipid soluble components nor did we examine distribution of the antioxidative activity in the body of squid. It is under investigation.

Although the antioxidative ability of squid lipid is far weaker than that of BHT and BHA when compared by weight ( $1 / 37$ of that of BHT, data not shown), it may be advantageous in practical usage. This is because its use is not restricted by food hygiene law. When rat was fed squid phospolipid, carbon tetrachloride-induced liver injuries of the rat was prevented. This will de reported elsewhere ${ }^{25)}$.

Acknowledgment: The authors wish to express their sincere gratitude to $\mathrm{Dr}$. Mamoru SAto, Assoc. Prof. at Kyoto University, Faculty of Agriculture for analyzing tocopherols of squids, and to Nippon Kagaku Shiryo Co., Ltd. for their kind donation of the purified

1* Personal communication from Dr. Mamoru Sato, Kyoto University, Faculty of Agricul ture. sardine oil. The authors wish also to express their thanks to Dr. Junji TeraO, of the National Food Research Institute, for his useful and valuable suggestion on the manuscript.

\section{References}

1) ResurRection, A.V.A. and ReYnolds, Jr., A.E. : J. Food Sci., 55, 627 (1990).

2) YamaGuchi, N., OKada, Y. and Naito, S. : Nippon Shokuhin Kogyo Gakkaishi, 37, 676 (1990).

3) Barbut, S., Josephson, D.B. and Maurer, A.J. : J. Food Sci, 50, 1357 (1985).

4) Lee, J.H., Fujimoto, K. and Kaneda, T.: Nippon Suisan Gakkaishi, 47, 881 (1981).

5) Bilinski, E., Jonas, R.E.E. and LAU, Y.C.: J. Fish. Res. Board Can., 35, 473 (1978).

6) YukI, E.: Nippon Shokuhin Kogyo Gakkaishi., 9, 149 (1962).

7) Ishikawa, Y. and Yuki, E. : Agric. Biol. Chem., 38, 1227 (1974).

8) Folch, J., Lees, M. and Sloane Stanley, G.A. : J. Biol. Chem., 226, 497 (1957).

9) Kumazawa, H. and Oyama, T. : Yukagaku, 14, 167 (1965).

10) Tipton, C.L., Paulis, J.W. and Pierson, M.D. : J. Chromatog., 14, 486 (1964).

11) Skipski, V.P., Peterson, R.F. and BarcLAY, M. : Biochem. J., 90, 374 (1964).

12) Fewster, M.E., Burus, B.J. and Mead, J.F. : J. Chromatog., 43, 120 (1969).

13) Fiske, C.H. and Subarrow, Y. : J. Biol. Chem., 66, 375 (1925).

14) Komatsu, I., Yasuda, T., FukunaGa, K., Suzuki, T., Suzuki, S. and Takama, K.: Bull. Fac. Fish. Hokkaido Univ., 41, 232 (1990).

15) Y AMAGUCH, K. and Toyomizu, M. : Nippon Suisan Gakkaishi, 50, 1897 (1984).

16) OlcotT, H.S. and VAN DeR VeEN, J.: $J$. Food Sci., 28, 313 (1962).

17) Hildebrand, D.H., Terao, J. and Kito, M. : J. Am. Oil Chem. Soc., 61, 552 (1984).

18) Hudson, B.J.F., Ghavami, M. : Lebensm. Wiss. Technol., 17, 191 (1984).

19) Ka.jimoto, G., OONishi, H., Hiromi, H. and ShIbahara, A. : Nippon Nogeikagaku Kaishi, 61, 191 (1987).

20) Yamaguchi, K., Toyomizu, M. and NAKAMURA, T.: Nippon Suisan Gakkaishi, 50, 1245 (1984). 
21) TAKagi, T., Ishizawa, T. and IIDA, T.: Yukagaku, 28, 548 (1979).

22) Terao, J.: Biochim. Biophys. Acta, 1003, 221 (1989).

23) Miyazawa, T., Yamaguchi, M., Lee, J.H., Fujmoto, K. and Kaneda, T.: Agric. Biol. Chem., 8, 1375 (1984).

24) Lee, J.H., Fujimoto, K. and Kaneda, T. : Nippon Suisan Gakkaishi, 50, 1863 (1984).

25) Takama, K., Komatsu, I., Suzuki, T., Fukunaga, K. and Suzuki, S. : Proceedings of International Conference, Seafood 2000, Halifax, May 14-17, 1990 (Fishing News Books Co. Ltd.), in press.

(Received Nov. 9, 1990)

\section{イカ外套筋の脂質画分中に含まれる抗酸化性物質} 小松一郎*, ** ·安田俊隆 ${ }^{*} \cdot$ 福永健治 ${ }^{*}$ 鈴木鐵也*・鈴木 聡*・高間浩蔵*

* 北海道大学水産学部食品学科 （干041 北海道函館市港町 3丁目 1-1

** 現在 : 大塚化学株式会社食品研究所 （₹771-01 徳島県徳島市川内町加賀須野）

3 種類のイカ (アカイカ [Ommastrephes bartrami], スルメイカ [Todarodes pacificus]，アルゼンチンマ ツイカ [llex argentinus]）の外套筋から脂質を抽出 し，精製イワシ油に対する過酸化抑制能を過酸化物価 (PV)，カルボニル価 (CV) を指標に比較・検討した. その結果，いずれのイカ絵脂質抽出物もイワシ油の過酸 化を有意に抑制し，中でもアルゼンチンマッイカのそれ が最す強い抗酸化能を示した。アルゼンチンマッイカか ら調製したリン脂質画分を用いて精製イワシ油に対する 抗酸化性を調べた結果, 明らかな抗酸化性を示した。 そ の抗酸化能は脂質, 脂肪酸の違い, あるいは単にトコフ ェロール組成の違いで説明出来るあのではなく，リン脂 質画分が深く係わっていることが示唆された。 